\title{
Peran pengasuhan dalam pembentukan perilaku siswa SMA Muhammadiyah 2 Yogyakarta
}

\author{
Galih Nugraheni, a, ${ }^{*}$, Darmiyati Zuchdy ${ }^{\text {b, } 2}$ \\ ${ }^{a, b}$ Program Studi Pendidikan IPS, Program Pascasarjana, Universitas Negeri Yogyakarta, Yogyakarta, \\ Indonesia \\ ${ }^{1}$ galih.nugraheni@yahoo.com*,2 darmiyatiz@yahoo.com
}

*korespondensi penulis

\begin{tabular}{l}
\hline Informasi artikel \\
\hline Kata kunci: \\
Pengasuhan orang \\
tua, \\
Perilaku, \\
Peran pengasuhan
\end{tabular}

ABSTRAK

Penelitian ini bertujuan mendeskripsikan: (1) pengasuhan orang tua siswa SMA

Muhammadiyah 2 Yogyakarta, (2) perilaku siswa SMA Muhammadiyah 2 Yogyakarta dan (3) peran pengasuhan orang tua siswa SMA Muhammadiyah 2 Yogyakarta dalam pembentukan perilaku siswa. Penelitian ini menggunakan metode deskriptif kualitatif dengan pendekatan studi kasus, dilakukan di SMA Muhammadiyah 2 Yogyakarta dan dilaksanakan pada bulan Juni sampai dengan Desember 2014, dengan siswa sebagai subjek penelitian. Peneliti menggali informasi sampai pada titik jenuh menggunakan snowball sampling. Pengumpulan data melalui observasi langsung, wawancara mendalam, dan dokumentasi. Validitas data dalam penelitian menggunakan teknik informant review dan triangulasi. Hasil penelitian ini adalah sebagai berikut: Pengasuhan orang tua yang mengedepankan komunikasi tidak didukung lingkungan yang baik menyebabkan perilaku anak tidak baik. Pengasuhan yang cenderung mengarah ke penekanan tidak didukung lingkungan yang baik akan menyebabkan perilaku anak tidak baik. Apalagi pengasuhan yang memberi kebebasan tidak didukung dengan lingkungan yang baik otomatis akan menyebabkan anak yang tidak baik. Pendidikan IPS khususnya sosiologi berperan sangat penting dalam memperbaiki perilaku menyimpang terhadap remaja di sekolah, serta berperan strategis dalam mewujudkan perilaku yang baik.

Keywords:

Parenting,

Behavior,

Parenting role

\begin{abstract}
The research aims to describe: (1) parenting of student of Muhammadiyah 2 Senior High School, Yogyakarta, (2) the behavior of the student of Muhammadiyah 2 Senior High School, Yogyakarta and (3) the role of parenting in the behavioral development of the students of Muhammadiyah 2 Senior High School, Yogyakarta. This research use descriptive qualitative method with a case study approach at Muhammadiyah 2 Senior High School, Yogyakarta and implemented from June to December 2014 with the subjects was its students. The researcher probed further information until the saturation point using the snowball sampling method. The data was collected through direct observation, interviews and documentation. The validity of the data used the informant review and triangulation technique. The results are Parenting emphasizes communication not supported by a good environment causes the child's behavior to be bad. Parenting likely to lead to the suppression and not supported by a good environment will cause the behavior of children not good. Moreover, parenting that gives freedom not supported by a good environment will automatically cause children to be not good. Social education especially sociology plays an important role improving the deviant behavior of juvenile in schools, and plays a strategic role in realizing good behavior.
\end{abstract}

Copyright () 2018 Galih Nugraheni dan Darmiyati Zuchdy.. All Right Reserved

\section{PENDAHULUAN}

Perilaku antisosial merupakan isu yang menonjol dalam banyak komunitas yang berbeda. Menurut Burt \& Donnellan (2009), perilaku antisosial terdiri dari tindakan destruktif yang berbahaya bagi orang lain dalam masyarakat. Perilaku ini dapat mencakup kegiatan ilegal serta merugikan 
hubungan antar individu, seperti: pencurian, orang tua yang diamati, pola asuh positif ancaman, perkelahian, vandalisme, ditunjukkan oleh sifat alpha-linked seperti kekasaran, penggunaan obat-obatan terlarang, keramahan, kestabilan emosi, dan kesadaran. minum minuman keras di bawah umur, Orang tua yang memiliki sifat alpha-linked membuang sampah sembarangan, tinggi menunjukkan peningkatan relatif dari memanipulasi orang lain, pelecehan verbal, waktu ke waktu dalam mengasuh positif tidak masuk sekolah, tawuran, dan banyak mereka terhadap remaja, sedangkan orang tua lagi.

Sampai saat ini masih banyak perilaku bernuansa antisosial. Perilaku antisosial yang kadang-kadang ditunjukkan oleh sekelompok siswa SMA Muhammadiyah 2 Yogyakarta masih terus terjadi dan berpotensi terulang kembali secara tidak terduga. Terjadinya kadang hanya dipicu oleh perilaku sederhana seperti mencoret-coret di tembok-tembok jalan dengan menggambar logo geng SMA masing-masing sekolah. Perilaku mereka terlalu mementingkan ego masing-masing, sebagaimana layaknya remaja egonya masih menonjol. Tentu saja hal ini tidak sesuai dengan aturan sosial, nilai, norma yang berlaku di sekolah maupun di luar sekolah.

Penelitian tentang perilaku siswa (remaja) telah banyak dilakukan untuk menetapkan dan mendeteksi faktor yang menyebabkan perilaku. Beberapa diantaranya menunjukkan efek dari faktor yang berbeda terhadap perilaku, namun menunjukkan adanya keterkaitan orang tua dengan perilaku anak seperti dalam penelitian berikut ini. yang memiliki kadar rendah dari sifat alphalinked mengalami penurunan pengasuhan positif. (2) tingkat yang lebih tinggi dari sifat alpha-linked orang tua dapat dikaitkan dengan tingkat yang lebih tinggi dari sifat alphalinked remaja. Hasil ini menjelaskan hubungan antara orang tua dan kepribadian remaja.

Anak-anak yang menyaksikan perilaku orang tua dan kemungkinan model perilaku yang mereka lihat. Dapat menjadi strategi adaptif ketika seorang anak mencari panduan untuk perilakunya sendiri. Dengan demikian, kelangsungan antar generasi dalam kepribadian yang diamati dalam penelitian ini mencerminkan emulasi oleh remaja dari sifatsifat orang tua. Penelitian-penelitian tersebut secara konsisten menempatkan orang tua dalam pengasuhan memegang peran penting dalam pembentukan perilaku anak, namun belum menjelaskan faktor yang menjadi kontributor kuat terhadap perilaku antisosial. Gaya pengasuhan yang berbeda: authoritative, dan authoritarian (moderately

Schofield, T. J., Conger, R. D., Donnellan, M. B., Jochem, R., Widaman, K. F., \& Conger, K. J (2012) menyimpulkan: (1) kepribadian positif orang tua merefleksikan

supportive), menunjukkan kurangnya kontrol dan kurangnya dukungan dan perlindungan terhadap anak (Hoeve, Blokland, Dubas, Loeber, Gerris, Peter, Laan, 2008). Hoeve 
memfokuskan pada perilaku negatif orang tua, pengasuhan negatif termasuk perilaku seperti penyalahgunaan, penelantaran, atas kontrol, dan hukuman berat. Orang tua otoriter overprotective dan percaya pada hukuman berat, orang tua otoritatif menunjukkan dukungan tingkat tinggi dan memiliki komunikasi yang efektif dengan anak-anak mereka. Serba membolehkan, memberi kemerdekaan tinggi pada anak-anak, menyebabkan rendahnya tingkat bimbingan orang tua bimbingan (Schaffer, Clark, \& Jeglic, 2009). Meskipun literatur menunjukkan bahwa tekanan teman sebaya memiliki hubungan yang signifikan dengan perilaku antisosial, namun diperkirakan bahwa pengasuhan negatif akan memiliki dampak yang lebih besar daripada tekanan rekan sebaya.

Masa remaja dapat dikatakan fase dengan banyak pengambilan keputusan berisiko (Terzian, 2011, hal.1). Kita dapat melihatnya pada siswa melalui berbagai keputusan yang dilakukan, contoh berupa pelanggaran peraturan sekolah atau norma-norma yang ada di sekolah. Seiring dengan perubahan cepat dalam masyarakat, tuntutan sosial dan standar telah berubah. (Yekta, 2011, hal.1), hal ini tentu akan mewarnai perilaku remaja secara umum dan siswa secara khusus.

Orang tua dapat memberikan pengaruh dalam pembentukan perilaku remaja yang akan dibawa selama hidupnya. Pembentukan masa depan baik melalui cita-cita maupun hal lainnya merupakan keinginan orang tua terhadap anaknya. Hal tersebut menjadikan orang tua memberikan model pembimbingan yang sesuai dengan apa yang selama ini dilaluinya dalam artian hal-hal yang baik. Model pembimbingan ini kerap disebut sebagai gaya pengasuhan orang tua (Salkind, 2008, hal. 852).

Notosoedirdjo \& Latipun (2011, hal. 207) menyatakan bahwa tata cara kehidupan keluarga akan membentuk sikap serta perkembangan kepribadian anak. Ketiga jenis tata cara kehidupan keluarga, yaitu: demokratis, anak dibesarkan dalam susunan keluarga yang demokratis, membuat anak mudah bergaul, aktif, dan ramah sehingga anak belajar menerima pandangan orang lain; permisif, anak yang dibesarkan dalam keluarga permisif akan membuat anak tidak aktif dalam kehidupan sosial dan dapat dikatakan anak menarik diri dari kehidupan sosial dan mempunyai kecenderungan untuk mudah membenci seseorang; otoriter, anak yang dibesarkan dalam keluarga yang otoriter biasanya akan bersifat tenang, tidak melawan, tidak agresif dan mempunyai tingkah laku yang baik. Anak akan berusaha menyesuaikan pendiriannya dengan kehendak orang lain (yang berkuasa, orang tua)

Aspek pola asuh orang tua yang sangat penting pada anak adalah penerimaan dan kontrol. Penerimaan adalah dukungan dan kasih sayang yang terlihat dari senyuman, pujian, dan dorongan. Kontrol mengacu pada pengawasan terhadap aktivitas anak (Shaffer and Kipp, 2014, hal. 541). Pola asuh ini 
tampak dari pelaksanaan peranan keluarga.

Dalam hal ini, terdapat empat prinsip peranan keluarga, yaitu modeling, mentoring, organizing, dan teaching (Yusuf, 2008, hal. 47).

Penelitian ini akan bertumpu pada penelitian-penelitian tersebut sebelumnya antara lain: 1) Charles Desforges (2003) dalam The Impact Of Parental Involvement, Parental Support And Family Education On Pupil Achievement And Adjustment: A Literature Review), 2) Susan H. Landry (2014) dalam The role of parents in early childhood learning, 3) Thomas J. Schofield (2012) dalam Parent Personality and Positive Parenting as Predictors of Positive Adolescent Personality Development Over Time. Untuk menjelaskan peran pengasuhan terhadap pembentukan perilaku siswa SMA Muhammadiyah 2 Yogyakarta. Dalam lingkungan keluarga anak akan memperoleh pelajaran yang mendasar. Pelajaran tersebut akan berguna untuk masa depannya. Fenomena tersebut diatas perlu segera mendapat perhatian yang serius, agar segera dapat diketemukan penjelasannya. Persoalanpersoalan tersebut diatas sangat erat kaitannya dengan pendidikan Ilmu Pengetahuan Sosial, kerena perilaku menyimpang ke pelanggaran yang dilakukan oleh siswa SMA Muhammadiyah 2 Yogyakarta dapat dianggap sebagai sumber masalah yang dapat membahayakan tegaknya sistem sosial. Dalam kaitannya dengan sosiologi banyaknya terjadi penyimpangan perilaku pelanggaran dikalangan siswa SMA Muhammadiyah 2 Yogyakarta dari berbagai aturan sosial, nilai, norma yang berlaku akibat pengaruh lingkungan sosial, tentunya dapat meresahkan.

Berdasarkan kenyataan yang terjadi, dapat diidentifikasi masalah-masalah sebagai berikut. Kurangnya intensitas pertemuan dan intensifnya hubungan anak dengan orang tua mengakibatkan tidak adanya keharmonisan antara anak dengan orang tua, Orang tua adalah faktor dasar dalam pembentukan perilaku remaja, Pergaulan dalam lingkungan sosial dan teman sebaya sangat mempengaruhi perilaku anak. Anak cenderung meniru model perilaku orang tua sejak kecil.

\section{METODE}

Jenis penelitian ini menggunakan metode deskriptif kualitatif dengan pendekatan studi kasus, kenakalan remaja yang sering terjadi seperti adanya tawuran antar SMA dan vandalisme antar pelajar SMA. Metode penelitian kualitatif merupakan metode yang digunakan untuk meneliti kondisi yang alamiah. Metode ini digunakan untuk mendapatkan data yang sebenarnya. Penelitian ini diharapkan dapat mengungkapkan berbagai macam informasi dengan deskripsi analisis yang penuh makna. Data-data yang dikumpulkan berupa katakata, dan gambar. Data tersebut diperoleh melalui hasil wawancara, catatan lapangan, foto, handycam, dokumentasi, catatan, dan dokumen resmi lainnya. 
Peneliti mendeskripsikan gambaran terjaring memalui teknik snowball antara lain tentang peran pola asuh orang tua terhadap adalah teman sekelas informan utama, teman siswa. Hal ini berkaitan dengan bagaimana sekolah, teman tim basket dan sepak bola, cara orang tua dalam mengasuh anak, guru BK, orang tua informan utama, dan sehingga hal tersebut dapat diketahui melalui pendekatan deskriptif kualitatif.

Seting penelitian ini dilakukan di SMA Muhammadiyah 2 Yogyakarta. Lokasi penelitian ini dipilih berdasarkan berbagai pertimbangan, salah satunya karena sekolah tersebut sering terlibat tawuran pelajar antar sekolah, vandalisme dan budaya ngompas terhadap SMA lainnya. Penulis mendapatkan informasi dari alumni yang pernah berkecimpung dalam "GANK Ranger". Penulis melaksanakan penelitian ini dalam jangka waktu tujuh bulan, dimulai pada bulan Juni sampai dengan Desember 2014.

Proses analisis data pada penelitian ini melalui empat tahapan yaitu pengumpulan data, reduksi data, penyajian data dan penarikan kesimpulan.

\section{HASIL DAN PEMBAHASAN}

Informan dalam penelitian ini adalah siswa SMA Muhammadiyah 2 Yogyakarta. Berdasarkan purposive sampling diambil lima orang sebagai informan. Kelima informan tersebut adalah sebagai berikut.

Tabel 1. Informan Penelitian

\begin{tabular}{cccc}
\hline No & Inisial & Umur (tahun) & Kelas \\
\hline I & RM & I8 & XI IPS 3 \\
2 & NS & I8 & XI IPA 3 \\
3 & AY & I8 & XI IPA 3 \\
4 & AM & I8 & XI IPA 3 \\
5 & SM & I8 & XI IPA 2 \\
\hline
\end{tabular}

Selain lima informan di atas, terdapat informan-informan lain yang terjaring melalui teknik snowball. Informan-informan yang

alumni SMA Muhammadiyah 2 Yogyakarta yang pernah menjadi anggota geng RANGER.

Dari informan-informan tersebut didapatkan data yang belum dapat diungkapkan melalui kelima informan utama dan menguatkan data yang telah didapat dari kelima informan utama.

Peneliti mengungkap pengasuhan orang tua tidak dengan cara langsung mendatangi rumah siswa kemudian mengobservasi atau mewawancari orang tua siswa,melainkan dengan cara tidak langsung melalui wawancara dengan siswa, pendekatan ini dilakukan dengan pertimbangan efektifitas dan objektivitas. Peneliti mengajukan sepuluh pertanyaan untuk mengungkap pengasuhan dalam wawancara tersebut.

Pengasuhan yang diterapkan oleh orang tua memiliki peran dalam kehidupan anak. Pengasuhan tersebut membentuk sebuah kebiasaan tertentu, sehingga menciptakan perilaku tertentu pada diri anak. Namun, pengasuhan orang tua bukan satu-satunya yang menentukan perilaku anak karena faktor lingkungan turut menentukan perilaku anak. Orang tua RM dan AM menerapkan pengasuhan dengan mengedepankan komunikasi (berinteraksi) dan rasionalitas, orang tua NS mengedepankan penerapan aturan yang ketat, sedangkan orang tua AY dan SM menerapkan pengasuhan dengan 
mengedepankan pemberian kebebasan untuk mengatur tingkah lakunya, orang tua melakukan kontrol sangat sedikit. Dari macam pengasuhan dapat kita lihat bahwa setiap orang tua memiliki gaya masingmasing dalam mendidik anak-anaknya. Bukan hanya dari orang tua saja perilaku setiap anak terbentuk, melainkan faktor lingkungan sangat berpengaruh dalam pembentukan perilaku.

Pengasuhan yang diterapkan oleh orang tua memiliki peran dalam kehidupan anak. Pengasuhan tersebut membentuk sebuah kebiasaan tertentu, sehingga menciptakan perilaku tertentu pada diri anak. Selain pengasuhan faktor lingkungan pergaulan juga mempengaruhi perilaku anak (siswa). Karakteristik yang berbeda antara RM, NS, AY, AM, dan SM dalam perilaku di atas merupakan gambaran dari hasil pengaruh pengasuhan orang tua mereka yang berbedabeda.

Dapat diamati dalam penelitian ini bahwa hasil menunjukkan pengasuhan orang tua yang mengedepankan komunikasi (interaksi) dan rasionalitas membentuk anak yang kurang baik akibat pengaruh lingkungan pergaulan. Pengasuhan orang tua yang ketat membentuk anak yang kurang baik, akibat pengaruh pergaulan. Apalagi pengasuhan orang tua yang memberikan kebebasan pada anak (siswa), otomatis faktor dari lingkungan keluarga dan lingkungan pergaulan sangat berpengaruh pada perilaku anak (siswa).
Peran pengasuhan terhadap pembentukan perilaku siswa tersebut secara teori dapat dijelaskan sebagai berikut menggunakan teori pengondisian operan dalam (Feist, 2010, hal. 168-169), tiga kondisi harus ada antara lain Antessenden (A), perilaku (B), dan konsekuensi (C). Antesenden (A) merujuk pada sebuah lingkungan atau situasi ketika perilaku muncul., lingkungan dapat berupa rumah atau tempat-tempat lainnya yang anak tersebut mungkin akan menggunakan pakaiannya. Kondisi kedua yang penting dalam adalah perilaku (B) anak laki-laki yang menggunakan pakaiannya sendiri. Respons harus berada dalam jangkauan anak laki-laki tersebut dan tidak boleh diganggu oleh perilaku kompetitif atau antagonis, seperti distraksi dari saudara kandung atau dari televisi.

Konsekuensi (C) yang dipersiapkan adalah permen, apabila penguatan meningkatkan kemungkinan bahwa suatu respons dapat terulang, lalu bagaimana perilaku dapat dibentuk dari sesuatu yang secara relatif tidak dibeda-bedakan menjadi sesuatu yang sangat kompleks. Organisme tidak hanya mengulang respons lama yang telah diberikan penguatan, namun bergerak bertahap menuju suatu perilaku yang diharapkan. Karena perilaku tidak terpisah, melainkan berkelanjutan, yaitu organisme biasanya bergerak sedikit diluar respons yang sebelumnya diberikan penguatan.

Dijelaskan dalam teori itu bahwa ada keterkaitan antara aktivitas pergaulan dan 
kondisi siswa (pengasuhan orang tua). Terkait dalam (Feist, 2010, hal.168-169) sebagai dengan temuan ini, dapat dilihat pada tabel berikut.

dan analisisnya berdasarkan teori Skiner

Tabel 2. Deskripsi Perilaku Siswa

\begin{tabular}{|c|c|c|}
\hline No & Nama & Perilaku \\
\hline 1 & RM & $\begin{array}{l}\text { Pribadi yang cenderung cuek, tidak menyukai dengan kondisi tekanan } \\
\text { tinggi, egois, memiliki rasa humor tinggi, bersemangat dan baik hati. }\end{array}$ \\
\hline 2 & NS & $\begin{array}{l}\text { Tekanan tinggi selalu membuat NS menjadi emosi, memiliki keinginan } \\
\text { kuat untuk mendapatkan sesuatu, solidaritasnya tinggi. }\end{array}$ \\
\hline 3 & AY & $\begin{array}{l}\text { Pribadi yang cuek, emosi yang belum stabil, tidak menyukai } \\
\text { persaingan, memiliki rasa simpati dan empati yang cukup tinggi. }\end{array}$ \\
\hline 4 & AM & $\begin{array}{l}\text { Senang berinstrospeksi, mampu mengendalikan emosi dan selalu } \\
\text { membantu teman dalam masalah. Akan tetapi mudah terpengaruh oleh } \\
\text { faktor lingkungan. }\end{array}$ \\
\hline 5 & SM & $\begin{array}{l}\text { Dalam kondisi emosi dia memilih diam (cuek). Empati dan simpati } \\
\text { rendah, tertutup sifatnya, tidak mengetahui urusan orang lain. }\end{array}$ \\
\hline
\end{tabular}

Perilaku pelanggaran yang dilakukan aktivitas pergaulan dan kondisi siswa oleh siswa SMA meliputi Muhammadiyah 2 (pengasuhan orang tua). Terkait dengan Yogyakarta seperti membolos, tawuran, temuan ini, dapat dilihat pada tabel dan vandalisme, merokok, dan ngompas dapat analisisnya berdasarkan teori Skiner dalam dalam teori itu bahwa ada keterkaitan antara (Feist, 2010, hal.169) sebagai berikut:

Tabel 4. Perilaku A B C Siswa SMA Muhammadiyah II Yogyakarta

\begin{tabular}{|c|c|c|c|c|}
\hline No & Nama & $\begin{array}{c}\text { (A) } \\
\text { Ante-senden }\end{array}$ & $\begin{array}{c}\text { (B) } \\
\text { Perilaku } \\
\end{array}$ & $\begin{array}{c}(\mathrm{C}) \\
\text { Konsekuensi } \\
\end{array}$ \\
\hline 1. & \begin{tabular}{|l} 
RM \\
Pengasuhan \\
mengedepan-kan \\
komunikasi.
\end{tabular} & $\begin{array}{l}\text { Lingkungan pergaulan di } \\
\text { sekolah maupun luar } \\
\text { sekolah. }\end{array}$ & $\begin{array}{l}\text { Membolos, tawuran, } \\
\text { Vandalisme, } \\
\text { merokok, ngompas }\end{array}$ & $\begin{array}{l}\text { Ditegur guru BK, } \\
\text { mendapatkan peringatan, } \\
\text { mendapatkan poin } \\
\text { pelanggran, diberi } \\
\text { hukuman, orang tua } \\
\text { dipanggil kesekolah. }\end{array}$ \\
\hline 2. & $\begin{array}{l}\text { AM } \\
\text { Pengasuhan } \\
\text { mengedepan-kan } \\
\text { komunikasi. }\end{array}$ & $\begin{array}{l}\text { Lingkungan pergaulan di } \\
\text { sekolah maupun luar } \\
\text { sekolah. }\end{array}$ & $\begin{array}{l}\text { Membolos, tawuran, } \\
\text { merokok, ngompas }\end{array}$ & $\begin{array}{l}\text { Ditegur guru BK, } \\
\text { mendapatkan peringatan, } \\
\text { mendapatkan poin } \\
\text { pelanggran, diberi } \\
\text { hukuman, orang tua } \\
\text { dipanggil kesekolah. }\end{array}$ \\
\hline 3. & $\begin{array}{l}\text { NS } \\
\text { Pengasuhan aturan } \\
\text { yang ketat. }\end{array}$ & $\begin{array}{l}\text { Lingkungan pergaulan di } \\
\text { sekolah maupun luar } \\
\text { sekolah. }\end{array}$ & $\begin{array}{l}\text { Membolos, } \\
\text { vandalisme, merokok }\end{array}$ & $\begin{array}{l}\text { Ditegur guru BK, } \\
\text { mendapatkan peringatan, } \\
\text { mendapatkan poin } \\
\text { pelanggran, diberi } \\
\text { hukuman. }\end{array}$ \\
\hline 4. & $\begin{array}{l}\text { AY } \\
\text { Pengasuhan yang } \\
\text { memberikan } \\
\text { kebebasan. }\end{array}$ & $\begin{array}{l}\text { Lingkungan pergaulan di } \\
\text { sekolah maupun luar } \\
\text { sekolah. }\end{array}$ & $\begin{array}{l}\text { Membolos, tawuran, } \\
\text { vandalisme, } \\
\text { merokok. }\end{array}$ & $\begin{array}{l}\text { Ditegur guru BK, } \\
\text { mendapatkan peringatan, } \\
\text { mendapatkan poin } \\
\text { pelanggran, diberi } \\
\text { hukuman. }\end{array}$ \\
\hline
\end{tabular}




\begin{tabular}{|l|l|l|l|l|}
\hline 5. & $\begin{array}{l}\text { SM } \\
\text { Pengasuhan yang } \\
\text { memberikan } \\
\text { kebebasan. }\end{array}$ & $\begin{array}{l}\text { Lingkungan pergaulan di } \\
\text { sekolah maupun luar } \\
\text { sekolah. }\end{array}$ & $\begin{array}{l}\text { Membolos, tawuran, } \\
\text { merokok, ngompas. }\end{array}$ & $\begin{array}{l}\text { Ditegur guru BK, } \\
\text { mendapatkan peringatan, } \\
\text { mendapatkan poin } \\
\text { pelanggran, diberi } \\
\text { hukuman, orang tua } \\
\text { dipanggil ke sekolah. }\end{array}$ \\
\hline
\end{tabular}

Berdasarkan tabel diatas dapat dijelaskan degan teori ABC Skiner dalam (Feist, 2010, hal. 169), bahwa perilaku yang dilakukan RM dapat dianalisis menggunakan teori ABC. Anteseden (A) yang merujuk pada sebuah lingkungan atau situasi ketika perilaku muncul berawal dari lingkungan pergaulan. Kemudian perilaku (B), yang dilakukan oleh RM adalah membolos, tawuran, vandalisme, merokok dan ngompas. Akibatnya RM Ditegur guru BK, mendapatkan peringatan, mendapatkan poin pelanggaran, diberi hukuman dan orang tua dipanggil ke sekolah.

Perilaku AM tidak jauh beda dengan perilaku pelanggaran yang dilakukan oleh $\mathrm{RM}$, hanya di bagian vandalisme AM tidak melakukannya. Anteseden (A) yang merujuk pada sebuah lingkungan atau situasi ketika perilaku muncul berawal dari lingkungan pergaulan. Kemudian perilaku (B), yang dilakukan oleh AM adalah membolos, tawuran, merokok dan ngompas. Akibatnya RM Ditegur guru BK, mendapatkan peringatan, mendapatkan poin pelanggaran, diberi hukuman dan orang tua dipanggil ke sekolah.

Perilaku pelanggaran yang dilakukan oleh NS berbeda dengan RM dan AM pada bagian tawuran dan ngompas NS tidak melakukannya. Anteseden (A) yang merujuk pada sebuah lingkungan atau situasi ketika perilaku muncul berawal dari lingkungan pergaulan. Kemudian perilaku (B), yang dilakukan oleh AM adalah membolos, vandalisme dan merokok. Akibatnya RM ditegur guru BK, mendapatkan peringatan, mendapatkan poin pelanggaran, diberi hukuman.

Perilaku AY tidak jauh beda dengan perilaku pelanggaran yang dilakukan oleh RM, hanya di bagian ngompas AY tidak melakukannya. Anteseden (A) yang merujuk pada sebuah lingkungan atau situasi ketika perilaku muncul berawal dari lingkungan pergaulan. Kemudian perilaku (B), yang dilakukan oleh AY adalah membolos, tawuran, vandalisme dan merokok. Akibatnya AY Ditegur guru BK, mendapatkan peringatan, mendapatkan poin pelanggaran, diberi hukuman dan orang tua dipanggil ke sekolah.

Perilaku pelanggaran yang dilakukan SM tidak jauh beda dengan perilaku pelanggaran yang dilakukan oleh RM. Perbedaannya pada vandalisme SM tidak melakukannya. Anteseden (A) yang merujuk pada sebuah lingkungan atau situasi ketika perilaku muncul berawal dari lingkungan pergaulan. Kemudian perilaku (B), yang dilakukan oleh RM adalah membolos, tawuran, merokok dan 
ngompas. Akibatnya RM Ditegur guru BK, mendapatkan peringatan, mendapatkan poin pelanggaran, diberi hukuman dan orang tua dipanggil ke sekolah.

Pembelajaran IPS menjadi salah satu kunci utama guna penyelesaian persoalanpersoalan tentang perilaku remaja diatas. Selain sebagai kunci penyelesaian persoalan diatas, IPS dapat mengajarkan dan membentuk perilaku sosial anak. Bertolak dari uraian diatas dapat kita lihat peran pendidikan IPS khususnya sosiologi keluarga. Keluarga adalah lembaga pendidikan terkecil tempat sebuah kehidupan dimulai dan saat pendidikan dimulai. Pendidikan keluarga adalah sebuah proses pemindahan dan pembentukan kehidupan yang ada dalam diri bapak dan ibu. Sebagian masyarakat menyatakan bahwa pergelutan dan kejayaan kehidupan keseharian lebih berarti dari pada persekolahan resmi (pendidikan formal). Pendidikan yang tidak resmi ini justru berlangsung lama karena anak-anak dari keluarga akan mendirikan keluarga baru ketika dewasa dan pendidikan keluarga akan berlangsung lagi kemudian. (Salim, 2008, hal. 164).

Perilaku anak (siswa) terbentuk tidak hanya dari faktor pengasuhan orang tua, akan tetapi karena faktor lingkungan pergaulannya sehingga mempengaruhi perilakunya. Berkaitan dengan pengasuhan dan pembentukan perilaku yang terjadi pada anak (siswa) tidak lepas dari faktor lingkungan, hal ini sesuai dengan teori sosiologi tentang interaksionisme simbolik.

Teori interaksionisme simbolik telah berkembang dan diperhalus menjadi prosesproses sosial yang terjadi di tingkat mikro, termasuk kesadaran subjektif dan dinamika interaksi antar pribadi. interaksionisme simbolik adalah: saling ketergantungan antara konsep diri dan organisasi sosial, gambaran tentang kenyataan sosial yang muncul dari komunikasi simbolik, tekanan pada asal usul sosial dari konsep diri dan sikap-sikap seseorang, ide bahwa respons terhadap stimulus lingkungan sangat bervariasi dan mencerminkan arti subjektif yang dimiliki bersama, dan penggunaan konsep-konsep sosial secara meluas seperti peran, melaksanakan peran dan pengambilan peran (Mead dalam Smart, hal. 176-177) Kemudian Mead tidak hanya bertolak dari perilaku individu akan tetapi juga kelompok kerja sama yang terdiri dari organisme yang berbeda-beda, aktivitas-aktivitas kolektif dari sebuah kelompok yang kemudian dinamakannya tindakan sosial (social act). Melihat perilaku remaja yang menyimpang di SMA Muhammadiyah 2 Yogyakarta, hal ini sesuai dengan teori interaksionisme simbolik pada masyarakat. Guru sebaiknya menggunakan metode yang tepat bagi pembelajaran, sehingga dapat menjelaskan kepada siswa tentang pengaruh interaksionisme simbolik. Pembelajaran IPS khususnya sosiologi dapat dilakukan diluar 
ruangan sehingga siswa dapat mengamati langsung kondisi yang sesuai di lapangan.

Para sosiolog berpendapat penyebab perilaku delinkuen pada anak-anak remaja saat ini, seperti halnya penyimpangan yang dilakukan SMA Muhammadiyah 2 Yogyakarta adalah murni sosiologis atau sosial psikologis sifatnya. Misalnya disebabkan oleh pengaruh struktur sosial, tekanan kelompok, peranan sosial, status sosial atau oleh internalisasi simbolis yang keliru dan tipisnya nilai dan norma sosial. Maka faktor-faktor kultur dan sosial itu sangat mempengaruhi, bahkan mendominasi struktur-struktur lembaga sosial dan peranan sosial setiap individu di tengah masyarakat, status individu di tengah kelompoknya partisipasi sosial dan pendefinisian diri atau konsep dirinya. (Kartono, 2014, hal. 28).

Melihat hasil penelitian di SMA Muhammadiyah 2 Yogyakarta, tentu saja peran orang tua yang kurang dalam pengasuhan selama mereka berada di dalam rumah, dapat membentuk perilaku yang tidak baik pada anak (siswa). Didukung dengan lingkungan yang kurang baik secara otomatis akan membentuk perilaku anak yang tidak baik. Pengaruh sosial kultural (budaya dalam lingkungan pergaulan) memiliki peranan yang besar dalam pembentukan atau pengondisian perilaku menyimpang (nakal) anak-anak remaja pada saat ini. Perilaku remaja yang menunjukkan tanda-tanda kurang atau tidak adanya norma-norma sosial. Pengaruh lingkungan justru menjadi pengaruh yang sangat kuat dibandingkan dengan pengasuhan dari orang tua selama mereka berada dilingkungan rumah. Sehingga peran IPS khususnya (sosiologi) sangat dibutuhkan oleh lembaga sekolah guna menjembatani perilaku-perilaku menyimpang yang dilakukan oleh siswa (anak). Dengan IPS khususnya (Sosiologi) seorang guru dapat dengan mudah menyampaikan materi yang bersifat wacana tentang remaja berikut perilaku pelanggarannya. Kemudian seorang guru dapat memberi penjelasan dampak negatif perilaku-perilaku menyimpang sehingga dapat memerikan pemikiran pada siswa (anak) untuk takut melakukannya. Guna memberi pemahaman yang lebih pada siswa, pendidikan IPS (Sosiologi) khususnya, diberikan oleh seorang guru dengan cara mengajak terjun langsung ke lapangan sehingga siswa dapat mengamati langsung fenomena sosial yang ada di lapangan. Sehingga bagi siswa yang perilakunya baik dalam arti tidak ada penyimpangan dapat semakin berwaspada dan bagi yang sudah terlanjur berperilaku menyimpang akan merasakan efek jera.

\section{SIMPULAN}

Pengasuhan dengan mengedepankan komunikasi (interaktif) idealnya dapat membentuk seorang anak (siswa) yang baik, akan tetapi akibat lingkungan pergaulan menjadikan anak (siswa) berperilaku tidak baik. Pengasuhan dengan mengedepankan aturan yang ketat membentuk perilaku anak (siswa) tidak baik, apalagi didukung oleh 
lingkungan yang tidak baik. Pengasuhan yang memberikan kebebasan anak mengatur tingkah laku dirinya membentuk perilaku anak tidak baik didukung lingkungan pergaulan yang tidak baik juga.

\section{DAFTAR PUSTAKA}

Burt, S.A., Donnellan, M.B. (2009). Development and validation of the subtypesof antisocial behavior. Questionnaire Department of Psychology, Michigan State University, Michigan, US.

Desforges, C, Abouchaar, A. (2003). The impact of parental involvement, parental support and family education on pupil achievement and adjustment: a literature review. Queen's Printer 2003, British Columbia, Canada.

Feist, J.J. (2010). theories of personality, Jakarta: Salemba Humanika.

Hoeve, M., Blokland, A., Dubas, J.S., Loeber. R., Gerris J.R.M, Peter H. Laan, V.D. (2008). Trajectories of delinquency and parenting styles. Springer Science Business Media, LLC 2007, London.

Notosoedirdjo, M. \& Latipun, (2011). Kesehatan mental, Malang, UPT Universitas Muhammadiyah Malang Press.

Salkind, N.J., (2008). Encyclopedia of educational psychology. SAGE Publications, Inc., California, USA.

Schaffer, M., Clark, S., Elizabeth, Jeglic (2009). The role of empathy and parenting style in the development of antisocial behaviors. John Jay College of Criminal Justice, New York.

Shaffer, D.R, Kipp (2014). Developmen-tal psychology: childhood an adoles-cence, 9th Edition. Canada: Wadswort Cengage Learning.

Schofield, T. J., Conger, R. D., Donnellan, M. B., Jochem, R., Widaman, K. F., \& Conger, K. J. (2012). Parent personality and positive parenting as predictors of positive adolescent personality development over time. Merrill-Palmer quarterly (Wayne State University. Press), 58(2), 255.

Terzian, M.A., Kristine, Andrews, Moore, K.A. (2011). Preventing multiple risky behaviors among adolescents: seven strategies. Bethesda, Wahsington.

Thomas, Schofield, Conger, R.D, (2008). Parent personality and positive parenting as predictors of positive adolescent personality development over time. Michigan State University, Michigan, US.

Yekta, M.S., Paranda, A., Zamania, N., Lotfia, S., Ayazia, M. (2011). Teaching problem-solving for parents: effects on children's misbehavior. College of Psychology and Educational Science, University of Tehran, Tehran, Iran.

Yusuf, S. (2008). Psikologi perkembangan anak \& remaja. Bandung: PT. Remaja Rosdakarya. 